\title{
Fuzzy context specific matched molecular pairs
}

\author{
Peter Schmidtke*, Vincent le Guilloux \\ From 9th German Conference on Chemoinformatics \\ Fulda, Germany. 10-12 November 2013
}

Matched molecular pairs (MMPs) are commonly used to assess the importance of chemical modifications on small molecules versus a particular property [1]. One major advantage of MMPs is the direct interpretation by medicinal chemists. Despite the popularity of MMPs several drawbacks hinder their systematic applications in drug discovery projects. First, in order to derive sufficiently representative statistics for extracting design rules rather large datasets of molecules and activities are needed. Second, MMPs are often used without context specificity, likely because of the lack of sufficient data. This results in weak statistics. One transformation could result to be beneficial, but is detrimental in reality once the context taken into account [2]. Context specific MMP analysis is clearly advantageous for in depth understanding of SAR, but hindered due to lack of data.

Here we present a novel methodology for providing robust statistics for fuzzy context specific MMPs even on medium sized data-sets. Molecules are transformed to a reduced graph using the Discngine Pharmacophore Graph methodology [3], a molecular graph reduction method closely related to classical reduced graphs [4]. Next, molecular fragmentation and MMP detection is directly performed on the pharmacophore graph. The herein used pharmacophore graph representation allows to group together very similar contexts and/or fragments and thus increase population size compared to classical MMP analysis.

Validation of the fuzzy context specific MMP (fcsMMP) is presented and outcome is compared to classical MMP analysis. Last the Discngine Network framework is used to organize the derived design rules for efficient large scale mining and results extraction in a real world Med Chem context and applications are shown.

Published: 11 March 2014 * Correspondence: peter.schmidtke@discngine.com
Discngine SAS, Paris, 75011, France

References

1. Leach AG, Jones HD, Cosgrove DA, Kenny PW, Ruston L, MacFaul P, Wood JM, Colclough N, Law B: Matched Molecular Pairs as a Guide in the Optimization of Pharmaceutical Properties; a Study of Aqueous Solubility, Plasma Protein Binding and Oral Exposure. J Med Chem 2006, 49(23):6672-6682.

2. Papadatos G, Alkarouri M, Gillet VJ, Willett P, Kadirkamanathan V, Luscombe CN, Bravi G, Richmond NJ, Pickett SD, Hussain J, Pritchard JM, Cooper AW, Macdonald SJ: Lead optimization using matched molecular pairs: inclusion of contextual information for enhanced prediction of HERG inhibition, solubility, and lipophilicity. J Chem Inf Model 2010, 50:1872-1886.

3. Discngine SAS: Pharmacophore Graph Pipeline Pilot Collection. Paris, France.

4. Birchall K, Gillet VJ: Reduced graphs and their applications in chemoinformatics. Methods Mol Biol 2011, 672:197-212.

doi:10.1186/1758-2946-6-S1-P44

Cite this article as: Schmidtke and le Guilloux: Fuzzy context specific matched molecular pairs. Journal of Cheminformatics 2014 6(Suppl 1):P44.

\footnotetext{
Publish with ChemistryCentral and every scientist can read your work free of charge

"Open access provides opportunities to our colleagues in other parts of the globe, by allowing anyone to view the content free of charge."

W. Jeffery Hurst, The Hershey Company.

- available free of charge to the entire scientific community

- peer reviewed and published immediately upon acceptance

- cited in PubMed and archived on PubMed Central

- yours - you keep the copyright

Submit your manuscript here:

http://www.chemistrycentral.com/manuscript/

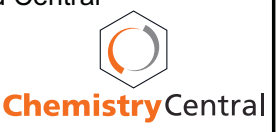

(c) 2014 Schmidtke and le Guilloux; licensee Chemistry Central Ltd. This is an Open Access article distributed under the terms of the Creative Commons Attribution License (http://creativecommons.org/licenses/by/2.0), which permits unrestricted use, distribution, and reproduction in any medium, provided the original work is properly cited. The Creative Commons Public Domain Dedication waiver (http://creativecommons.org/publicdomain/zero/1.0/) applies to the data made available in this article, unless otherwise stated. 